\title{
TRANSFORMATIONS OF EARTHWORM COMMUNITIES DURING POST- LOGGING SUCCESSIONS IN THE FORESTS OF THE NORTHWEST CAUCASUS
}

\section{A.P. Geraskina}

Center for Forest Ecology and Productivity of the RAS

Profsoyuznaya st. 84/32 bldg. 14, Moscow, 117997, Russia

E-mail: angersgma@gmail.com

Received 11 November 2018

The paper presents study findings of the earthworm population at three phases of postlogging succession of coniferous-broad-leaved forests in the Northwest Caucasus (heads of the Pshekha and Belaya rivers). Three types of forest communities corresponding to the stages of forest vegetation succession were examined: early stage - aspen-hornbeam-honeysuckle smallgrass forests, intermediate stage - fir-hornbeam small-grass forests, late stage - beech-fir deadcover forests. Type of soil: brown forest soils. It has been shown that during the post-logging succession significant changes in the earthworm community occur only at the late stage, when the biomass of anecic worms increases significantly. Only at the late stage there are four stable morpho-ecological groups of Lumbricidae, despite the fact that at this stage the structure of ecological-cenotic plant groups becomes simpler and oligodominant dead-cover communities with a predominance of boreal species are formed. At all stages, species with the CrimeanCaucasian type of habitat (D. schmidti, D. mariupolensis) are prevalent. Demographic structure of the earthworm community in all types of forests is stable, represented by different ontogenetic states with a significant predominance of juvenile worms (65-78\%).

Key words: Northwest Caucasus, succession, earthworms, Lumbricidae, forest, soil

Earthworms as one of the main factors causing decay of the leaf and herbaceous debris in the forests of the European part of Russia are inextricably linked with the forest type and age (Perel, 1959; Lavrov, Shelukho, 1997; Vsevolodova-Perel et al., 1995, etc.). Varying debris quality, stand canopy closure, and window mosaic pattern have a significant impact on the mesofauna in general and specifically on earthworms (Sariyildiz et al., 2004; Sariyildiz, Küçük, 2008; Kooch, 2010; Schelfhout et al., 2017). The transformations of the Lumbricidae community in fallow successions are well studied and they are used as an example of gradual restoration of the full-fledged soil-forming community of earthworms including all morpho-ecological groups: epigeic, epi-endogeic, endogeic and anecic species (Pizl, 1992; Scheu, 1990, 1992; Geraskina, 2009; 2016). In the literature there are data on the transformations of earthworm communities in forests at different stages of post-logging successions in Central Russia (Lavrov, 1969; Dorokhov, Isachenkov, 2007; Geraskina, 2009; 2016). The available literature gives no 
information about any studies focusing on the earthworm population dynamics in forests at the different succession stages formed after logging in the Northwest Caucasus.

Study objective: to assess the dynamics of earthworm communities in coniferous-broadleaved forests at different stages of post-logging succession in the Northwest Caucasus.

\section{MATERIALS AND METHODS}

Studies were carried out in summer 2016 at three stages of post-logging succession of the forests in the Northwest Caucasus (heads of the Pshekha and heads of the Belaya river) at an altitude of $650-700 \mathrm{~m}$ above sea level were analyzed. Based on the population-ontogenetic approach to the state of plant communities (Smirnova et al., 1988; 2006; Evstigneev et al., 1992; Smirnova, 2004) three stages of succession were identified: early - aspen-hornbeamhoneysuckle small-grass forests, intermediate - fir-hornbeam small-grass forests, late - beechfir dead-cover forests with the oldest trees of over 450 years old (Shevchenko et al., 2019). At each stage three experimental plots $50 \times 50 \mathrm{~m}^{2}$ in size were allotted. Soil and zoological studies were carried out according to the standard method: 16 soil samples $25 \times 25 \mathrm{~cm}$ in size were taken up to the depth of species occurrence from the experimental plots with different stages of succession (Gilyarov, 1975). Earthworms (Lumbricidae) in the soil and fauna in deadwood were counted. Data on the quantity and biomass are given only based on the results of soil sample analysis. Earthworms were fixed in $95 \%$ alcohol. Earthworm species were identified using the guide of T. S. Vsevolodova-Perel (1997). Morpho-ecological groups of Lumbricidae are given according to the classification of T. S. Perel (1979). The following ontogenetic states were included into the earthworm demographic structure: juvenile, subadults and adults (Shashkov, 2016). Cocoons of earthworms were not assessed separately.

Geobotanical and soil descriptions (Kuznetsova et al., 2019; Shevchenko et al., 2019) were made for each of the experimental plots of the three stages of succession.

Statistical data processing was carried out using MS Excel 2016 software packages. Parameters found during calculations: mean $(\mathrm{X})$, standard error of mean (SE), median (M), quartiles $(\mathrm{Q} 1, \mathrm{Q} 3)$.

\section{RESULTS AND DISCUSSION}

In three forest types 8 species of earthworms were identified belonging to 4 morphoecological groups and 4 types of habitats (Table 1).

Species composition of earthworms and composition of morpho-ecological groups in general is in line with the earthworm population in similar forest types in the medium-altitude mountain forests of the Northwest Caucasus (Rapoport, 2014; Rapoport, Tsepkova, 2015; Geraskina, 2016). 
Table 1. Species composition, types of habitat and morpho-ecological groups of earthworms of coniferous-broad-leaved forests of the Northwest Caucasus

\begin{tabular}{|c|c|c|c|}
\hline No. & $\begin{array}{c}\text { Species } \\
\text { Lumbricidae }\end{array}$ & Habitat & $\begin{array}{l}\text { Morpho-ecological } \\
\text { group }\end{array}$ \\
\hline 1. & $\begin{array}{l}\text { Dendrobaena shmidti shmidti } \\
\text { (Michaelsen, 1907) }\end{array}$ & \multirow{2}{*}{ Crimean-Caucasian } & endogeic \\
\hline 2. & $\begin{array}{l}\text { Dendrobaena mariupoliensis } \\
\text { (Wyssotzky, 1898) }\end{array}$ & & anecic \\
\hline 3. & $\begin{array}{l}\text { Dendrobaena attemsi } \\
\text { (Michaelsen, 1902) }\end{array}$ & \multirow{2}{*}{ Mediterranean } & epigeic \\
\hline 4. & $\begin{array}{l}\text { Aporrectodea jassyensis } \\
\text { (Michaelsen, 1891) }\end{array}$ & & \multirow[t]{2}{*}{ endogeic } \\
\hline 5. & $\begin{array}{l}\text { Dendrobaena tellermanica } \\
\text { (Perel, 1966) }\end{array}$ & East European and Asian & \\
\hline 6. & $\begin{array}{l}\text { Dendrodrilus rubidus tenuis } \\
\text { (Eisen, 1874) }\end{array}$ & \multirow{3}{*}{ Cosmopolitans } & \multirow{2}{*}{ epigeic } \\
\hline 7. & $\begin{array}{l}\text { Dendrobaena octaedra } \\
\text { (Savigny, 1826) }\end{array}$ & & \\
\hline 8. & $\begin{array}{l}\text { Esenia fetida } \\
\text { (Savigny, 1826) }\end{array}$ & & epi-endogeic \\
\hline
\end{tabular}

The total number of earthworms does not differ significantly in the three forest types with the different succession status and ranges from 36 to $42 \mathrm{spec} . / \mathrm{m}^{2}$ unlike biomass which at the late stage is twice as high compared to the previous stages (Fig. 1).

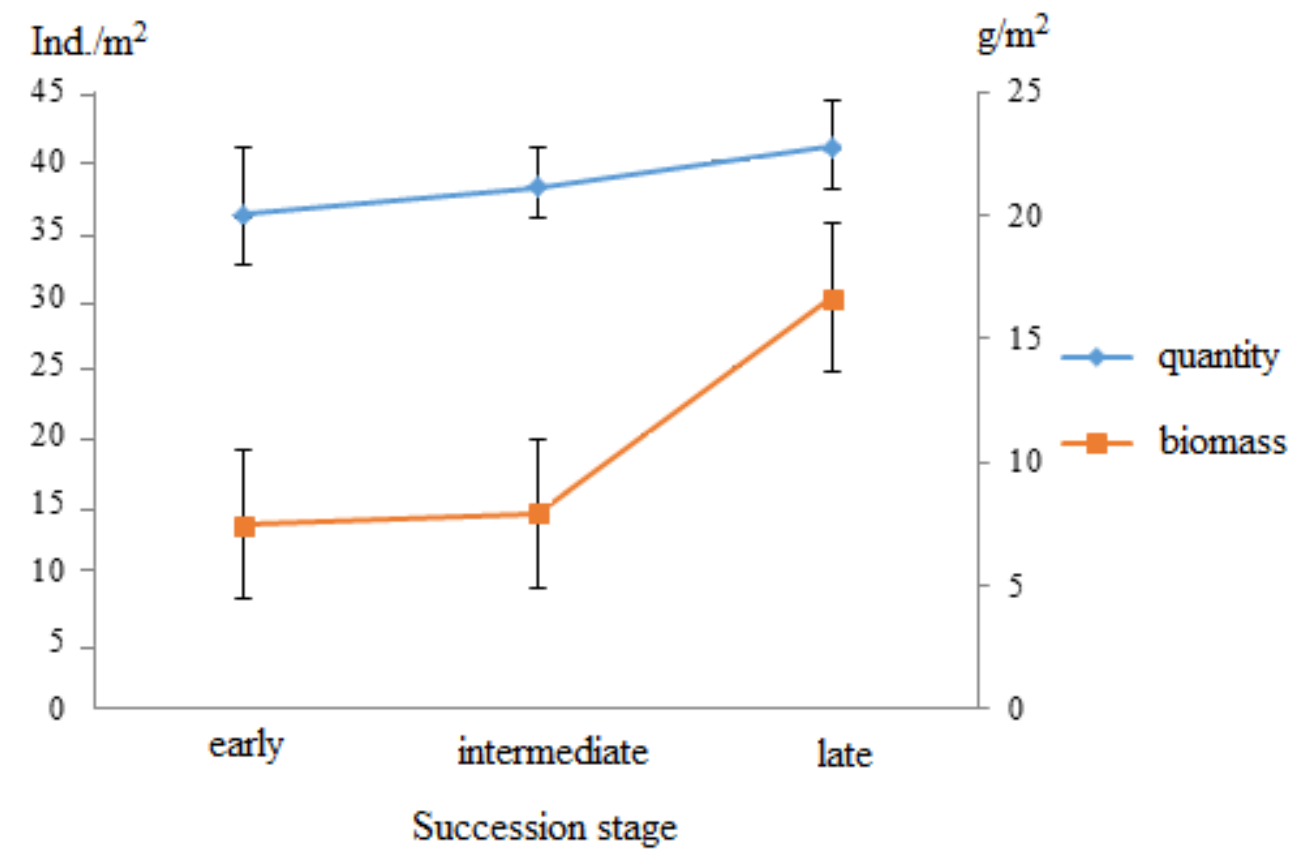

Figure 1. Dynamics of the quantity and biomass of earthworms at different succession stages of a coniferous-broad-leaved forest $(\mathrm{X} \pm \mathrm{SE}, \mathrm{n}=3)$ 
At the early succession stage aspen-hornbeam-honeysuckle small-grass forests are home to 7 species of earthworms: D. octaedra, D. attemsi, E. fetida, D. shmidti, A. jassyensis, D. tellermanica, and D. mariupoliensis. Fauna assessment in deadwood revealed only two species: D. attemsi and E. fetida. In soil, predominant species (80\%) in terms of both quantity and biomass are soil species D. schmidti and A. jassyensis (Fig. 2, 3). Demographic structure of the most numerous group of endogeic species D. shmidti, A. jassyensis, D. tellermanica is dominated by juvenile earthworms. At the same time $90 \%$ of specimens at the period of counting in the group of epigeic, epi-endogeic and anecic worms were adults and subadults (Fig. 4).

At the intermediate succession stage 5 species of earthworms were found in fir-hornbeam small-grass forests: D. octaedra, D. attemsi, D. schmidti, A. jassyensis and D. mariupoliensis, all species were found both in soil samples and in deadwood. At this stage of succession, like at the previous stage, the group of endogeic species prevails (Fig. 2, 3). No epi-endogeic species were found. The biomass of epigeic species is increasing, but the biomass of anecic worms remains low. Demographic structure of the earthworm population is similar to that of the previous stage (Fig. 4).

At the late stage of succession beech-fir dead-cover forests are inhabited with 7 species of Lumbricidae: D. octaedra, De. r. tenuis, D. shmidti, A. jassyensis, D. mariupoliensis, D. attemsi and E. fetida. Two epigeic species, De. r. tenuis and D. attemsi, live mainly in deadwood. Beside epigeic species, epi-endogeic E. fetida and endogeic D. schmidti were found in deadwood. A significant increase in Lumbricidae biomass at the late stage (Fig. 1) is mainly due to the increase in the specimen number of the large anecic species D. mariupolensis (8 times as much as at the previous stages). Moreover, at this stage there is an increase in the number and biomass of endogeic species (mainly D. schmidti) (Fig. 3) as well as a decreased percent of small juvenile worms in the group (Fig. 4).

In the three forest types, species with Crimean-Caucasian and Mediterranean types of habitats prevail in terms of number and biomass, and the share of cosmopolitans is small. As a rule, cosmopolitan species of Lumbricidae are numerous in small-leaved and floodplain forests of the Northwest Caucasus (Rapoport, Tsepkova, 2015; Geraskina, Shevchenko, 2018), fir and hornbeam communities keep the "Caucasian face" of the Lumbricidae fauna (Rapoport, Tsepkova, 2015). 


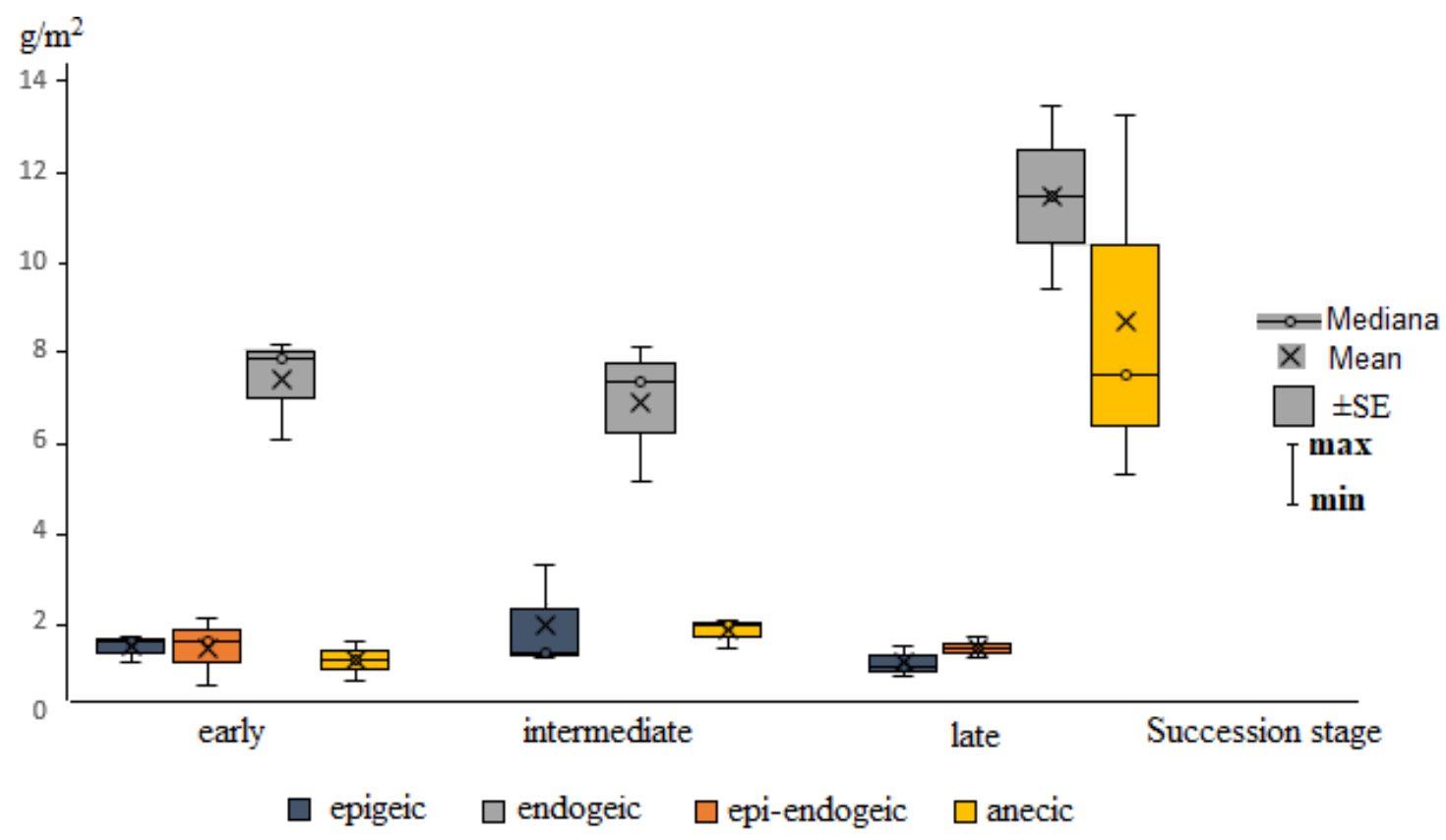

Figure 2. Dynamics of the biomass of morpho-ecological groups of earthworms at different stages of a coniferous-broad-leaved forest succession

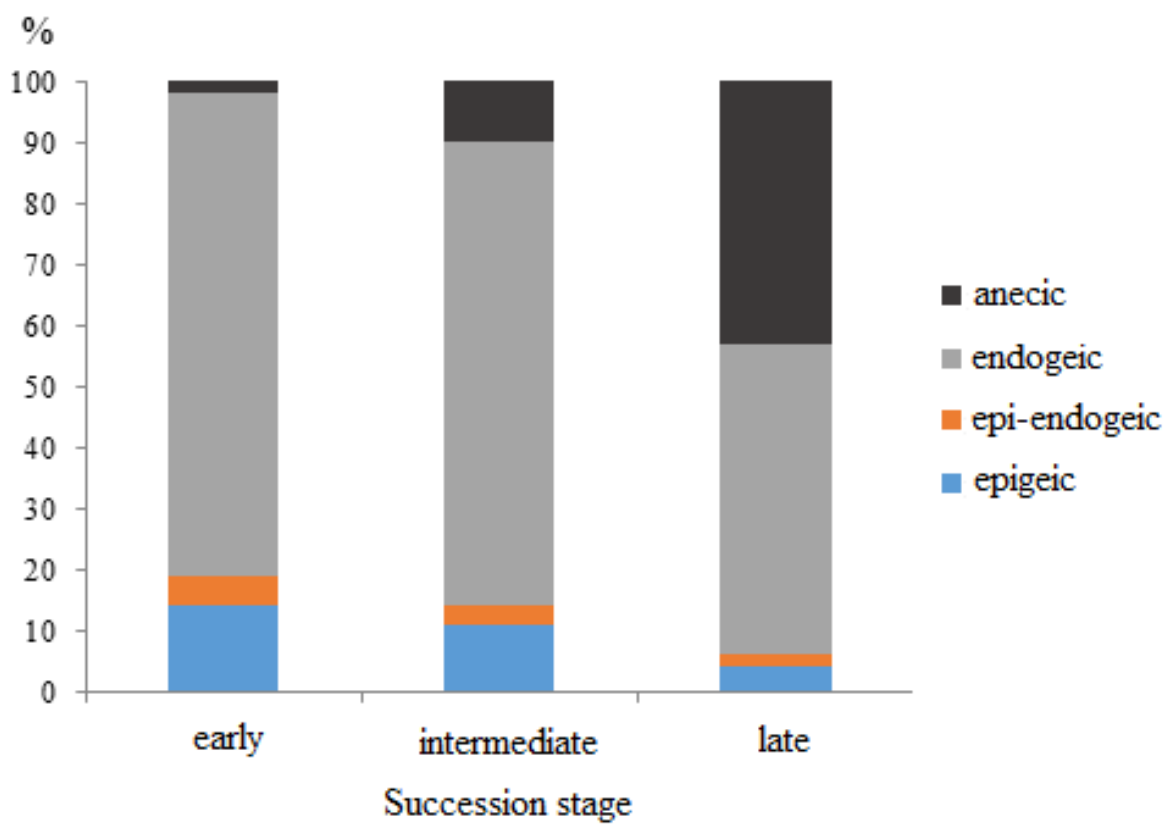

Figure 3. Share of total biomass of morphological groups of earthworms at different stages of a coniferous-broad-leaved forest succession 


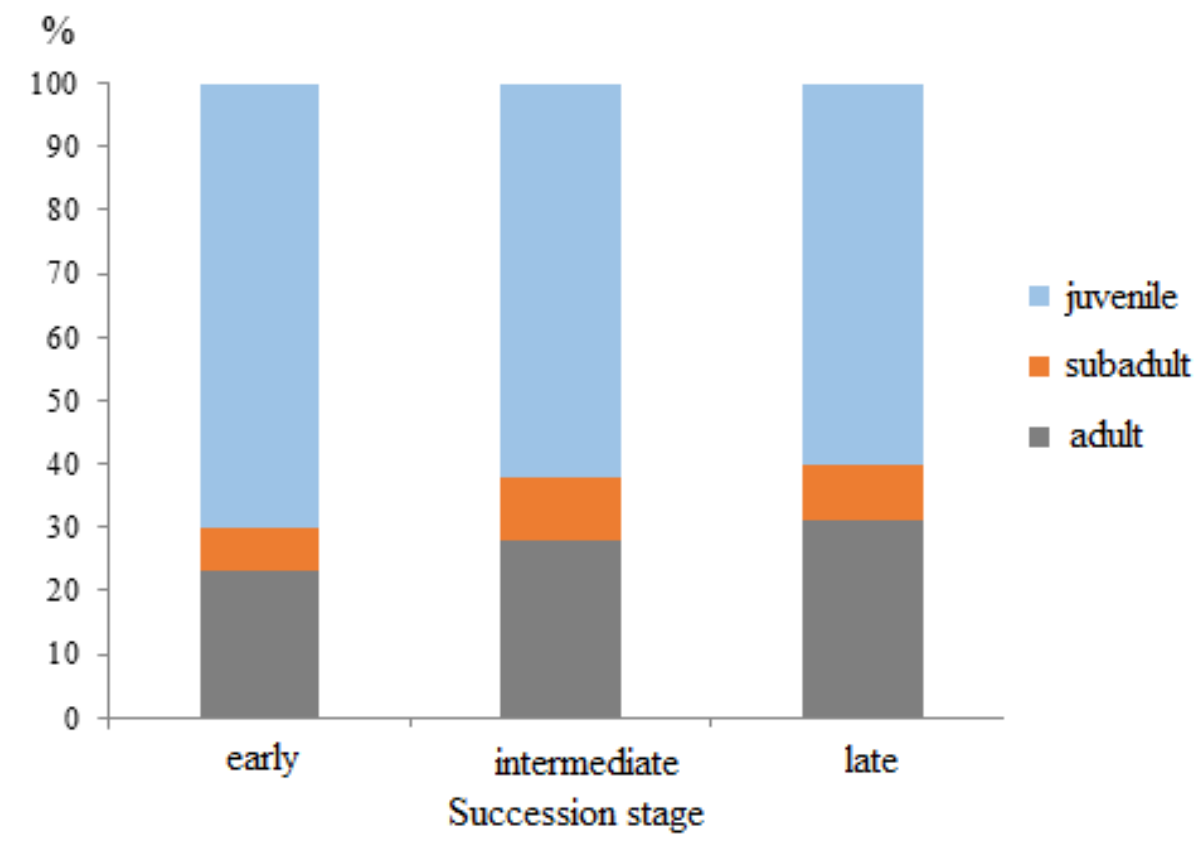

Figure 4. Share based on the number (quantity) of earthworms in different ontogenetic states at three succession stages of a coniferous-broad-leaved forest

Transformations of earthworm communities during post-logging successions in the moststudied forests of Central Russia are also intended to restore the diversity of morpho-ecological groups of Lumbricidae which is linked primarily to changes in litter properties during vegetation succession (Lavrov, 1969; Dorokhov, Isachenkov, 2007; Geraskina, 2009; 2016). In addition, window mosaic pattern and therefore the diversity of habitats in old forests contribute to the conservation of different groups of earthworms (Kooch, 2010; Schelfhout et al., 2017; Geraskina, Shevchenko, 2018).

In the present study, the properties of tree plant debris and ground cover are most favorable for saprophages at the early and intermediate stages - in aspen-hornbeamhoneysuckle small-grass and fir-hornbeam small-grass forests with a high share of nemoral, nitrophilous and meadow-forest-edge species (Shevchenko et al., 2019), where mixed litter from leaf debris of different tree and undergrowth species is formed. Most studies have shown the benefit of mixed deciduous and coniferous debris for the activity of the soil saprophage community (Sariyildiz et al., 2004; Sariyildiz, Küçük, 2008), since hard-to-decompose coniferous litter provides a favorable habitat for epigenic mesofauna, and easily decomposable deciduous debris provides an accessible source of carbon and nitrogen (Sayad et al., 2012). Studies in the forests of Central Germany have shown that the more diverse the composition of the forest stand is, the greater the density and higher the functional diversity of earthworms are. Monodominant beech forests are inhabited with only one group of epigeic earthworms (Cesarz et al., 2007). 
At a late stage, beech-fir dead-cover forests with a high proportion of boreal species, despite the unfavourable (in terms of trophic conditions) fir and beech debris, a full-fledged community of earthworms is formed. It has a high proportion of endogeic species and anecic $D$. mariupolensis which is evidence of favourable soil conditions of forest brown soils for earthworms and is indicative of the late succession stage in the forest development. The diversity of morpho-ecological groups of earthworms in forests with hard-to-decompose debris is also exemplified by beech forests of the Central Caucasus, which is associated with a favourable combination of soil conditions and the presence of a thick layer of slowlydecomposable litter (Rapoport et al., 2017).

\section{CONCLUSION}

At the three stages of post-logging succession of coniferous-broad-leaved forests in the Northwest Caucasus the species composition of earthworms remains to a large extent similar. At all stages, species with Crimean-Caucasian and Mediterranean types of habitats are prevalent, whereas the share of cosmopolitans is small. The demographic structure of the earthworm communities remains stable throughout the succession with a significant predominance of juvenile worms. Deadwood niches are of great importance in maintaining earthworm communities at all stages of succession: representatives of all morpho-ecological groups of earthworms were found there during the summer season.

During the post-logging succession significant transformations of earthworm communities occur only at the late stage with the significant increase in the biomass of anecic worms which are indicative of the late succession stages in the forest development. It is only at the late stage when four morpho-ecological groups of Lumbricidae live, consistently providing mineralization of plant debris at different stages despite the fact that at this stage the structure of ecologicalcenotic plant groups becomes simpler and that oligodominant dead-cover communities with a predominance of boreal species are formed.

\section{ACKNOWLEDGEMENTS}

Materials of the study were collected by of state assignment "Methodical approaches to the assessment of the structural organization and functioning of forest ecosystems"№ AAAAA18-118052400130-7, results of the study were processed by supported Russian Science Foundation (project 16-17-10284). 


\section{REFERENCES}

Cesarz S., Fahrenholz N., Migge-Kleian S., Platner C., Schaefer M. Earthworm communities in relation to tree diversity in a deciduous forest, European Journal of Soil Biology, 2007, Vol. 43, pp. 61-67.

Dorohova M.F., Isachenkov L.B. Biologicheskaya aktivnost' pochv vyrubok polosy shirokolistvenno-hvojnyh lesov yuzhnogo Podmoskov'ya (Biological activity of soil cuttings of a band of broad-leaved-coniferous forests in the southern Moscow region), Lesnoe pochvovedenie: itogi, problemy, perspektivy (Forest Soil Science: Results, Problems and Prospects), Proceedings of the international conference6 September 4-11, 2007, Syktyvkar, 2007, pp. 111-112.

Evstigneev O.I., Korotkov V.N., Bakalyna L.V. Populyacionnaya organizaciya grabovyh lesov Kanevskogo zapovednika (Population organization of hornbeam forests of the Kanev Reserve), Byul. Mosk. o-va ispytatelej prirody. Otd. biol., 1992, Vol. 97, No. 2, pp. 81-89.

Geras'kina A.P. Naselenie dozhdevyh chervej (Lumbricidae) na zarastayushchih polyah (Earthworm populations (lumbricidae) in soils of laylands), Zool. zhurn, 2009, Vol. 88, No 8, pp. 901-906.

Geras'kina A.P., Dozhdevye chervi (Oligochaeta, Lumbricidae) okrestnostej pos. Dombaj Teberdinskogo zapovednika (Severo-Zapadnyj Kavkaz, Karachaevo-Cherkessija) (Earthworms (Oligochaeta, Lumbricidae) near the township Dombay of Teberda Reserve (Northwest Caucasus, Karachay-Cherkessia), Trudy zool. instituta RAN, 2016, No 4, pp. 450-466.

Geras'kina A.P., Shevchenko N.E. Biotopicheskaya priurochennost' dozhdevyh chervej v malonarushennyh lesah Teberdinskogo biosfernogo zapovednika (Biotopic Association of Earthworms in Intact Forests of Teberda Nature Reserve), Lesovedenie, 2018, No 6, pp. 464-478.

Gilyarov M.S. Metody pochvenno-zoologicheskih issledovanij (Methods of soil and zoological research), Moscow: Nauka, 1975, 304 p.

Kooch Y., Hosseini S.M., Mohammadi J., Hojjati S.M. The Effects of Gap Disturbance on Soil Chemical and Biochemical Properties in a Mixed Beech-Hornbeam Forest of Iran, Ecologia Balkanica, 2010, Vol. 2, pp. 39-56.

Kuznecova A.I., Lukina N.V., Tihonova E.V., Gornov A.V., Gornova M.V., Smirnov V.E., Geras'kina A.P., Shevchenko N.E., Teben'kova D.N. Akkumulyaciya ugleroda v peschanyh i suglinistyh pochvah ravninnyh hvojno-shirokolistvennyh lesov $\mathrm{v}$ hode vosstanovitel'nyh sukcessij (Accumulation of carbon in sandy and sugline soils of plain of coniferous-broadenflow forests in the course of restorative successions), Pochvovedenie, 2019. (prinyata v pechat').

Lavrov M.T. Fauna pochv Bryanskogo lesnogo massiva v svyazi s tipami lesa i puti ee regulirovaniya, Avtoref. diss. dokt. biol. nauk (Soil fauna of the Bryansk forest area in connection with forest types and ways of its regulation. Abstract doctor's boil. sci. thesis), Kiev, 1969, 60 p. 
Lavrov M.T., Sheluho V.P. Razvitie ehkologicheskih issledovanij fauny bespozvonochnyh $\mathrm{v}$ Bryanskom lesnom massive (The development of ecological studies of the invertebrate fauna in the Bryansk forest), Izv. vuzov. Les. zhurn., 1997, No 1-2, pp. 25-29.

Perel' T.S. Dozhdevye chervi kak pokazatel' pochvennyh uslovij v lesonasazhdeniyah, Avtoref. ... diss. kand. biol. nauk (Earthworms as an indicator of soil conditions in forest stands. Abstract candidate's boil. sci. thesis), Moscow: MGPI, 1959, 14 p.

Pizl V. Succession of earthworm population in abandoned fields, Soil Biol. Biochem, 1992, Vol. 24, pp. 1623-1628.

Rapoport I.B., Biotopicheskoe raspredelenie dozhdevyh chervej (Oligochaeta, Lumbricidae) v Teberdinskoj zapovednoj territorii s naibolee vysokoj stepen'ju ohrany (Arhyzskij uchastok, Severo-Zapadnyj Kavkaz) (The biotopic distribution of earthworms (Oligochaeta, Lumbricidae) in Teberda conservation area of highest protection (Arkhyz section, northwestern Caucasus)), Sovremennye problemy osobo okhranyaemykh prirodnykh territorii regional'nogoznacheniya $i$ puti ikh resheniya (Recent Challenges and Solutions in Regional Protected Areas), Voronezh, 18 December 2014, Voronezh: Izd-vo VGU, 2014, pp. 214-218.

Rapoport I.B., Cepkova N.L., Struktura naselenija i topicheskie preferendumy dozhdevyh chervej (Oligochaeta, Lumbricidae) v pochvah jetalonnyh lesnyh formacij bassejnov rek Teberda i Bol'shoj Zelenchuk (Teberdinskij zapovednik, Severo-Zapadnyj Kavkaz) (Population structure and topical preferendum of earthworms (Oligochaeta, Lumbricidae) in the soils of normal forest formations of the Teberda and Bolshoi Zelenchuk river basins (Teberda Nature Reserve, NorthWestern Caucasus)), Izvestiya Samarskogo nauchnogo centra Rossiiskoi Akademii nauk, 2015, Vol. 17, No 6-1, pp. 33-39.

Rapoport I.B., Zenkova I.V., Tsepkova N.L., Earthworm (Oligochaeta, Lumbricidae) populations of the Karasu River basin (Central Caucasus), Biology Bulletin, 2017, Vol. 44, No. 8, pp. 941-951.

Sariyildiz T. Effects of tree canopy on litter decomposition rates of Abies nordmanniana, Picea orientalis and Pinus sylvestris, Scandinavian journal of forest research, 2008, Vol. 23, No. 4, pp. 330-338.

Sariyildiz T., Küçük M. Litter mass loss rates in deciduous and coniferous trees in Artvin,northeast Turkey: Relationships with litter quality, microclimate, and soil characteristics, Turkish journal of Agriculture and Forestr, 2008, Vol. 32, No. 6, pp. 547-559.

Sayad E., Hosseini S.M., Hosseini V., Salehe-Shooshtari M.H. Soil macrofauna in relation to soil and leaf litter properties in tree plantations, Journal of Forest Science, 2012, Vol. 58, No. 4, pp. 170-180. 
Shashkov M.P. Populyacionno-demograficheskie podhody k izucheniyu vnutripochvennyh dozhdevyh chervej v lesah Kaluzhskoj oblasti (Population demographic approaches to studies of earthworms in the forests of Kaluga Oblast), Lesovedenie, 2016, No 1. pp. 55-64.

Scheu S. Changes in microbial nutrient status during secondary succession and its modification by earthworms, Ecology, 1990, Vol. 84, pp. 351-358.

Scheu S. Changes in the Lumbricid coenosis during secondary succession from a wheat field to a beechwood on limestone, Soil Biol. Biochem, 1992, Vol. 24, No. 12, pp.1641-1646.

Smirnova O.V., Popadyuk R.V., Chistyakova A.A. Populyacionnye metody opredeleniya minimal'noj ploshchadi lesnogo cenoza (Population methods for determining the minimum area of forest cenosis), Bot. zhurn., 1988, Vol. 73, No 10, pp. 1423-1434.

Smirnova O.V. Metodologicheskie podhody i metody ocenki klimaksovogo i sukcessionnogo sostoyaniya lesnyh ehkosistem (na primere Vostochnoevropejskih lesov) (Methodological approaches and methods for assessing the climax and succession state of forest ecosystems (on the example of East European forests)), Lesovedenie, 2004, No 3, pp. 15-27.

Smirnova O.V., Bobrovskij M.V., Hanina L.G., Smirnov V.E. Bioraznoobrazie i sukcessionnyj status starovozrastnyh temnohvojnyh lesov Evropejskoj Rossii (Biodiversity and succession status of old-growing dark coniferous forests of European Russia), Usp. sovr. biol. 2006, Vol. 126, No 1. pp. 27-49.

20.

Schelfhout S., Mertens J., Verheyen K., Vesterdal L., Baeten L., Muys B., De Schrijver A. Tree species identity shapes earthworm communities, Forests, 2017, Vol. 8, No. 3. pp. 85-105.

Shevchenko N.E., Kuznecova A.I., Teben'kova D.N., Smirnov V.E., Geras'kina A.P., Gornov A.V., Tihonova E.V., Lukina N.V. Sukcessionnaya dinamika rastitel'nosti i zapasy pochvennogo ugleroda $\mathrm{v}$ hvojno-shirokolistvennyh lesah severo-zapadnogo Kavkaza (The succession dynamics of vegetation and carbon stocks in coniferous-deciduous forests of the north-western Caucasus), Lesovedeni,. 2019, (prinyata v pechat').

Vsevolodova-Perel' T.S., Dozhdevye chervi fauny Rossii. Kadastr i opredelitel' (Earthworms of Russia. Cadastr and key-book.). Moskow: Nauka, 1997, 101 p.

Vsevolodova-Perel' T.S., Gryuntal' S.Yu., Kudryasheva I.V., Nadtochij S.E., Golovach S.I., Matveeva A.A., Osipov V.V., Karpachevskij L.O., Rastvorova O.G. Struktura $i$ funkcionirovanie pochvennogo naseleniya dubrav Srednerusskoj lesostepi (The structure and functioning of the soil population of the oak forests of the Central Russian forest-steppe). Moscow: Nauka, 1995, 152 p. 
Reviewer: PhD in biology Rapoport I.B. 